Pembelajaran Menulis Teks ....(Liza Murniviyanti)

\title{
PEMBELAJARAN MENULIS TEKS BERITA TOKOH IDOLA DENGAN MEMPERHATIKAN MORFOFONEMIK SISWA
}

\author{
Oleh: Liza Murniviyanti \\ (Dosen Universitas PGRI Palembang) \\ Email: lizamurniviyanti@univpgri-palembang.ac.id
}

\begin{abstract}
Abstrak
Tujuan penelitian ini untuk mengetahui dan mendeskripsikan pengaruh model pembelajaran artikulasi terhadap kemampuan menuliskan kembali pokokpokok berita yang didengarkan siswa. Metode yang digunakan dalam penelitian ini adalah metode eksperimen dan teknik pengumpulan data dilakukan dengan teknik tes. Sampel dalam penelitian ini berjumlah 62 siswa yang terdiri atas dua kelas, yaitu kelas eksperimen berjumlah 31 siswa dan kelas kontrol berjumlah 31 siswa yang diambil menggunakan teknik random sampling. Berdasarkan hasil penelitian pada kesimpulan, dinyatakan bahwa menulis pokok berita kelas eksperimen yang diajarkan menggunakan model artikulasi lebih baik dari hasil belajar siswa kelas kontrol yang diajarkan dengan metode ceramah yang dilihat melalui pengujian hipotesis karena terbukti bahwa nilai $t_{\text {hitung }}$ lebih besar dari nilai $t_{\text {tabel }}$ sebesar 6,48>2,00 atau dilihat dari nilai rata-rata kelas eksperimen 74,5 lebih besar dibandingkan nilai rata-rata kelas kontrol 63,1. Hal tersebut menunjukkan adanya pengaruh model pembelajaran artikulasi terhadap hasil belajar siswa pada mata pelajaran Bahasa Indonesia pada materi menulis pokokpokok berita siswa kelas VIII MTs Nurul Himah.
\end{abstract}

Kata kunci: Model Pembelajaran Artikulasi, Menulis Pokok Berita

\section{TEXT WRITING LEARNING IN IDOLA FIGURE NEWS BY WATCHING THE MORFOFONEMICS STUDENTS}

\begin{abstract}
The purpose of this study was to determine and describe the influence of the learning model articulation on the ability to rewrite the headlines that were heard by students of MTs Nurul Himah Class, Palembang 41 Public Middle School. The method used in this study is the experimental method and the technique of data collection is done by test techniques. The sample in this study amounted to 66 students consisting of two classes, namely the experimental class amounted to 34 students and the control class amounted to 32 students taken using random sampling techniques. Based on the results of the research at the conclusion, it was stated that writing the headlines of the experimental class taught using the articulation model was better than the learning outcomes of the control class students taught by the lecture method seen through testing hypotheses because it proved that the value $t_{-}$(count) was greater than the value $t_{-}$(table) of 6.482 .00 or seen from the average value of the experimental class 74.5 greater than the average value of the control class 63.1. This shows the influence of the
\end{abstract}


articulation learning model on student learning outcomes on Indonesian language subjects in writing the news items of class VIII students of MTs Nurul Himah, Palembang Public Middle School 41 Palembang.

Keywords: articulation learning model, ability to write headlines

\section{A. PENDAHULUAN}

Bahasa secara linguistik merupakan alat yang bersifat arbitrer untuk dapat bekerja sama serta berinteraksi dengan manusia lainnya. Kata arbirer berarti sewenang-wenang, berubah-berubah, tidak tetap, mana suka yang dimaksud dengan arbirer adalah tidak adanya hubungan wajib antara lambang bahasa (yang berwujud bunyi) dengan konsep atau pengertian yang dimaksud oleh lambang tersebut (Kurnia, 2014:15).

Hampir semua aspek kehidupan manusia tidak lepas dari penggunaan bahasa. Bahasa sebagai bagian hidup yang bersifat universal atau umum memiliki peran penting. Peran bahasa sangat penting dalam kehidupan manusia sehingga tidak terlepas dari berbagai fungsi yang disandangnya. Fungsi bahasa yang paling mendasar yaitu sebagai alat komunikasi, alat pergaulan dan penghubung sesama manusia. Adanya komunikasi dua arah tidak terlepas dari fungsi dasar bahasa sebagai alat komunikasi. Pemakaian bahasa sebagai alat komunikasi ditentukan faktor kebahasaan (linguistik) dan nonkebahasaan (nonlinguistik) (Darmawati, 2009:1-2)

Morfofonemik atau yang biasa disebut dengan morfofonologi adalah ilmu yang menelaah morfofonem (atau bisa juga disingkat dengan morfofonem) (Tarigan, 2009:26). Morfofonologi adalah telaah umum mengenai bidang kebersamaan antara bunyi dan bentuk kata. Dalam morfofonologi kita tidak menelaah bunyi tunggal beserta varian-variannya saja, tetapi justru menelaah bunyi-bunyi rangkap beserta varian-variannya.

Morfofonemik dalam Berita Utama surat kabar Sumatera Ekspres ini di ambil sebagai rubrik yang mewakili keseluruhan isi berita. Adapun alasan peneliti memilih Berita Utama sebagai data utama yang akan di teliti karena di dalam Berita Utama ini banyak menggunakan pemakaian kata morfofonemik sehingga 
Pembelajaran Menulis Teks ....(Liza Murniviyanti)

akan lebih banyak data yang diperoleh untuk menganalisis peristiwa morfofonemik dan proses dalam morfofonemik.

Berdasarkan hasil pengamatan peneliti pada Berita Utama surat kabar Sumatera Ekspres pada 1 Maret 2018 yang berjudul Disambut Barongsai Terbangkan Lampion terdapat kajian morfofonemik pada kata "masing-masing, muda-mudi, jalan-jalan, kue-kue” yang termasuk kedalam kajian morfofonemik yaitu kajian reduplikasi serta kata "mem + padati" menjadi kata "memadati" termasuk kedalam perubahan fonem /N/ pada morfem meN- berubah menjadi fonem $/ \mathrm{m} /$ apabila bentuk dasar yang mengikutinya berawalan /p, b, f/. Ragam jurnalistik sangatlah berbeda dengan ragam bahasa yang digunakan manusia. ragam bahasa sering di sebut dengan variasi bahasa.

Darmawati (2009:3 - 4) variasi bahasa yang digunakan manusia bermacammacan jenisnya Ilmu yang mempelajari variasi/ragam bahasa dan penggunaan bahasa dalam masyarakat disebut sosiolinguistik. Suatu kajian sosiolinguistik adalah bahasa yang digunakan oleh masyarakat sehingga komunikasi lancer. Sosiolinguistik merupakan ilmu antardisiplin antara sosiologi dan linguistik, dua bidang ilmu empiris yang mempunyai kaitan yang sangat erat. Sosiologi adalah kajian yang objektif dan ilmiah mengenai manusia di dalam masyarakat, dan mengenai lembaga-lembaga, dan proses sosial yang ada di dalam masyarakat.

Sosiologi berusaha mengetahui bagaimana masyarakat itu terjadi, berlangsung dan tetap ada. Dengan mempelajari lembaga-lembaga sosial dan segala masalah sosial dalam masyarakat, akan diketahui cara-cara manusia menyesuaikan diri dengan lingkungannya, bagaimana mereka bersosialisasi dan menempatkan diri dalam tempatnya masing-masing pada masyarakat. Sedangkan linguistik adalah bidang ilmu yang mempelajari bahasa, atau bidang ilmu yang mengambil bahasa sebagai objek kajiannya. Dengan demikian, secara mudah dapat di katakan bahwa sosiolinguistik adalah bidang ilmu antardisiplin yang mempelajari bahasa dalam kaitannya dengan penggunaan bahasa itu di dalam masyarakat (Chaer dan Leoni, 2010:2)

Sumadia (2011:53) mengatakan bahwa bahasa yang lazim dipakai dalam media cetak berkala yaitu surat kabar, tabloid, dan majalah, disebut bahasa 
jurnalistik. Selain bahasa jurnalistik, kita juga mengenal bahasa jurnalistik radio, bahasa jurnalistik televisi, bahasa jurnalistik film, dan bahasa jurnalistik media online internet. Sebagai salah satu ragam bahasa, bahasa tunduk kepada kaidah dan etika bahasa baku.

Chaer (2012:2 -3) bahasa jurnalistik atau ragam-ragam jurnalistik mempunyai ciri-ciri sendiri yang membedakannya dengan ragam bahasa lainnya. Ciri-ciri ragam bahasa jurnalistik adalah sesuai dengan tujuan tulisan jurnalistik dan siapa pembaca ragam jurnalistik itu. Pembaca ragam jurnalistik adalah semua anggota masyarakat pada umumnya. Siapa saja boleh dapat menjadi pembaca karya jurnalistik.

Alasan peneliti memilih harian Sumatera Ekspres sebagai objek kajian karena surat kabar ini merupakan salah satu surat kabar terbesar di Sumatera Selatan. Selain itu, surat kabar harian Sumatera Ekspres merupakan harian lokal masyarakat Palembang yang memiliki reputasi cukup baik dalam masyarakat palembang. Alasan peneliti memilih judul ini karena penelitian ini sangatlah penting dalam media massa sehingga media massa dapat dikaji sebagai kajian morfofonemik. Selain itu, di dalam surat kabar ada beberapa kesalahan dalam penulisan dan berdasarkan sepengetahuan peneliti, dan penelitian ini belum pernah dilakukan di Universitas PGRI Palembang.

Sumatera Ekspres merupakan surat kabar yang telah lama berdiri dan setiap harinya mencetak 40 ribu eksemplar. Sumatera Ekspres juga memiliki media massa cetak yang berada di bawah naungannya yaitu, Palembang Pos, Babel Pos, Radar Palembang Monica, OKU Ekspres, Lahat Pos, Prabumulih Pos, Radar Lampung, dan Jambi Pos di samping itu juga Sumeks Grup memiliiki media elektronik yaitu Pal TV, dan Sumeks FM (dalam pengerjaan). Kantor Pusat Graha Pena, di jalan Kol H Burlian No 773 Palembang. Harian pagi Sumatera Ekspres Palembang menyajikan berita seputar nasional, internasional, olahraga, hiburan, ekonomi dan seluruh berita tentang Sumatera Selatan. Sumatera Ekspres merupakan surat kabar terbesar di Sumatera Selatan. 
Pembelajaran Menulis Teks ....(Liza Murniviyanti)

Mulae (2015:9) menyatakan afiks di ambil dari bahasa inggris yaitu affix dan memiliki pengertian adalah suatu bentuk linguistik yang di dalam suatu kata merupakan unsur langsung yang bukan kata dan bukan pokok kata yang memiliki kesanggupan melekat pada bentuk-bentuk lain untuk membentuk kata atau pokok kata baru dalam kata.

Afiks adalah sebuah bentuk, biasanya berupa morfem terikat, yang di imbuhkan pada sebuah dasar dalam proses pembentukan kata. Afiks dapat dikategorikan menjadi lima macam yaitu sebagai berikut.

a. Prefiks adalah afiks yang diletakkan dimuka bentuk dasar. Dalam bahasa Indinesia misalnya mem-, di-, ber-, ke-, ter-, se-, pem-, dan pe-/per-.

b. Infiks adalah afiks yang diletakkan di dalam bentuk dasar. Dalam bahasa Indonesia terdapat tiga macam infiks yaitu -el, -em, dan -er.

c. Sufiks adalah afiks yang diletakkan dibelakang bentuk. Dalam bahasa Indonesia misalnya -kan, -i, -nya, -wati, -wan, -man, -isme, -isasi.

d. Kombinasi afiks adalah proses pembentukan kata yang berupa pemberian afiks secara kombinasi dari dua afiks atau lebih yang dihubungkan dengan sebuah bentuk dasar. Dalam bahasa Indonesia misalnya dikenal beberapa kombinasi afik yaitu me-kan, me-i, memper-kan, memper-i, ber-kan, me-i, mem-kan, ber-, ter-kan, pe-an, dan se-nya.

e. Konfiks yang terdiri dari dua unsur, satu dimuka bentuk dasar dan satu di belakang bentuk dasar dan berfungsi sebagai satu morfem terbagi. Dalam bahasa Indonesia setidak-tidaknya. Terdapat empat konfiks yaitu ke-an, penan, dan ber-an. Konfiks-konfiks ini misalnya melekat pada pengiriman, persahabatan, berhalangan (Achmad, 2012:63).

Husnul (2010:47) berita adalah laporan tercepat mengenai fakta atau ide terbaru yang benar, menarik, dan penting bagi sebagian besar khalayak yang disebarluaskan melalui media massa berkala. Berita ditulis dengan kalimat yang singkat, padat dan jelas. 


\section{B. METODOLOGI PENELITIAN}

Metode yang digunakan dalam penelitian ini yaitu metode deskriptif kualitatif. Metode deskripstif kualitatif yaitu berupaya memecahkan masalah atau menjawab permasalahan yang dihadapi dengan cara mengumpulkan data, mengklasifikasi data, mengolah data, dan membuat kesimpulan.

Sumber data dalam penelitian ini adalah Berita Utama pada salah satu surat kabar terbitan Sumatera Selatan yaitu Sumatera Ekspress edisi 1--7 Maret 2018 yang berjumlah tujuh eksemplar yaitu 28 Berita Utama. Data yang digunakan adalah semua peristiwa morfofonemik, peristiwa morfofonemik yang terdapat dalam surat kabar Sumatera Ekspres seperti yang tercermin dalam ciri-ciri ragam jurnalistik dan proses morfofonemik.

Teknik pengumpulan data yang digunakan dalam penelitian ini adalah observasi dan dokumentasi. Teknik analisis data yang digunakan dalam penelitian ini adalah analisis isi (content analysis). Analisis ini adalah penelitian yang berusaha menganalisis isi dan makna yang ada pada dokumen.

\section{HASIL PENELITIAN DAN PEMBAHASAN}

Tabel 1 Data Hasil Siswa Tes Awal (Pre-Test) Siswa Kelas Eksperimen.

\begin{tabular}{|c|l|c|c|c|c|c|}
\hline No. & Nama & $\begin{array}{c}\text { Tata } \\
\text { bahasa }\end{array}$ & $\begin{array}{c}\text { Kosa } \\
\text { kata }\end{array}$ & EYD & Jumlah & Ket \\
\hline 1 & A P & 10 & 20 & 25 & 55 & TT \\
\hline 2 & A D & 17 & 15 & 28 & 60 & TT \\
\hline 3 & A L & 14 & 16 & 35 & 65 & TT \\
\hline 4 & A A & 15 & 25 & 30 & 70 & TT \\
\hline 5 & D N & 20 & 15 & 15 & 50 & TT \\
\hline 6 & D S & 15 & 20 & 21 & 56 & TT \\
\hline 7 & D F & 35 & 15 & 15 & 65 & TT \\
\hline 8 & D A & 15 & 25 & 35 & 75 & T \\
\hline 9 & H & 18 & 20 & 14 & 52 & TT \\
\hline 10 & I N S & 35 & 15 & 15 & 65 & TT \\
\hline 11 & Iq & 35 & 20 & 25 & 80 & T \\
\hline 12 & J W & 10 & 27 & 28 & 65 & TT \\
\hline 13 & J I & 35 & 15 & 30 & 80 & T \\
\hline 14 & M K PY & 15 & 15 & 23 & 53 & TT \\
\hline 15 & M S & 30 & 15 & 15 & 60 & TT \\
\hline
\end{tabular}


Pembelajaran Menulis Teks ....(Liza Murniviyanti)

\begin{tabular}{|c|l|c|c|c|c|c|}
\hline No. & \multicolumn{1}{|c|}{ Nama } & $\begin{array}{c}\text { Tata } \\
\text { bahasa }\end{array}$ & $\begin{array}{c}\text { Kosa } \\
\text { kata }\end{array}$ & EYD & Jumlah & Ket \\
\hline 16 & $\mathrm{~N} \mathrm{~L}$ & 20 & 10 & 15 & 45 & $\mathrm{TT}$ \\
\hline 17 & $\mathrm{~N} \mathrm{~S}$ & 25 & 25 & 25 & 75 & $\mathrm{~T}$ \\
\hline 18 & $\mathrm{P} \mathrm{A}$ & 12 & 20 & 30 & 62 & $\mathrm{TT}$ \\
\hline 19 & $\mathrm{Pr}$ & 20 & 20 & 24 & 64 & $\mathrm{TT}$ \\
\hline 20 & $\mathrm{Pu}$ & 21 & 19 & 10 & 50 & $\mathrm{TT}$ \\
\hline 21 & $\mathrm{R} \mathrm{W}$ & 20 & 15 & 15 & 50 & $\mathrm{TT}$ \\
\hline 22 & $\mathrm{Re}$ & 18 & 28 & 25 & 71 & $\mathrm{TT}$ \\
\hline 23 & $\mathrm{R} \mathrm{S}$ & 10 & 20 & 20 & 50 & $\mathrm{TT}$ \\
\hline 24 & $\mathrm{R} \mathrm{D}$ & 25 & 25 & 30 & 80 & $\mathrm{~T}$ \\
\hline 25 & $\mathrm{Sa}$ & 10 & 20 & 19 & 49 & $\mathrm{TT}$ \\
\hline 26 & $\mathrm{So}$ & 15 & 15 & 25 & 55 & $\mathrm{TT}$ \\
\hline 27 & $\mathrm{Su}$ & 24 & 15 & 20 & 59 & $\mathrm{TT}$ \\
\hline 28 & $\mathrm{U} \mathrm{M} \mathrm{P}$ & 35 & 20 & 15 & 70 & TT \\
\hline 29 & Wi & 12 & 13 & 35 & 60 & TT \\
\hline 30 & Y SP & 12 & 13 & 30 & 55 & TT \\
\hline 31 & Zu & 27 & 30 & 20 & 77 & T \\
\hline & Jumlah & & & & $\mathbf{1 9 2 3}$ & \\
\hline & Rata-rata & & & & $\mathbf{6 2 , 0 3}$ & Tidak tuntas \\
\hline
\end{tabular}

Tabel 2 Data Hasil Siswa Tes Awal (Pre-Test) Siswa Kelas Kontrol

\begin{tabular}{|c|l|c|c|c|c|c|}
\hline No. & Nama & $\begin{array}{c}\text { Tata } \\
\text { bahas } \\
\text { a }\end{array}$ & $\begin{array}{c}\text { Kosa } \\
\text { kata }\end{array}$ & EYD & Jumlah & Ket \\
\hline 1 & An & 12 & 18 & 24 & 54 & TT \\
\hline 2 & A U & 15 & 9 & 4 & 28 & TT \\
\hline 3 & An & 15 & 10 & 20 & 45 & TT \\
\hline 4 & A P & 30 & 20 & 15 & 65 & TT \\
\hline 5 & A S & 22 & 15 & 10 & 47 & TT \\
\hline 6 & A K D & 17 & 10 & 14 & 41 & TT \\
\hline 7 & A G & 10 & 16 & 10 & 36 & TT \\
\hline 8 & B G & 30 & 15 & 8 & 53 & TT \\
\hline 9 & Be & 30 & 20 & 10 & 60 & TT \\
\hline 10 & C M P & 18 & 10 & 6 & 34 & TT \\
\hline 11 & D A & 30 & 25 & 25 & 80 & T \\
\hline 12 & El & 12 & 20 & 20 & 52 & TT \\
\hline 13 & Er & 25 & 10 & 15 & 50 & TT \\
\hline 14 & F H & 11 & 9 & 4 & 24 & TT \\
\hline 15 & G S & 30 & 15 & 15 & 60 & TT \\
\hline 16 & G A & 18 & 9 & 5 & 32 & TT \\
\hline 17 & Ii & 30 & 15 & 20 & 65 & TT \\
\hline 18 & I T & 10 & 9 & 10 & 29 & TT \\
\hline
\end{tabular}


Wahana Didaktika Vol. 17 No.3 September 2019 : 287-296

\begin{tabular}{|l|l|c|c|c|c|c|}
\hline No. & Nama & $\begin{array}{c}\text { Tata } \\
\text { bahas } \\
\text { a }\end{array}$ & $\begin{array}{c}\text { Kosa } \\
\text { kata }\end{array}$ & EYD & Jumlah & Ket \\
\hline 19 & NS & 14 & 9 & 9 & 32 & TT \\
\hline 20 & PS & 10 & 10 & 9 & 29 & TT \\
\hline 21 & PSAT & 15 & 15 & 5 & 35 & TT \\
\hline 22 & PY & 18 & 20 & 13 & 51 & TT \\
\hline 23 & PD & 30 & 15 & 15 & 60 & TT \\
\hline 24 & RS & 10 & 12 & 13 & 35 & TT \\
\hline 25 & Ro & 15 & 15 & 35 & 75 & T \\
\hline 26 & SP & 15 & 30 & 25 & 70 & TT \\
\hline 27 & Sa & 10 & 15 & 15 & 40 & TT \\
\hline 28 & SA & 35 & 30 & 15 & 80 & T \\
\hline 29 & SJ & 20 & 10 & 10 & 40 & TT \\
\hline 30 & Ti & 19 & 20 & 30 & 69 & TT \\
\hline 31 & Wi & 17 & 15 & 20 & 52 & TT \\
\hline & Jumlah & & & & $\mathbf{1 5 2 3}$ & \\
\hline & Rata-rata & & & & $\mathbf{4 9 , 1 2}$ & Tidak tuntas \\
\hline
\end{tabular}

\section{Pembahasan}

Penelitian ini bertujuan untuk mengetahui adakah pengaruh strategi pembelajaran modeling dalam menulis teks berita siswa kelas VIII MTs Nurul Hikmah Desa Cinta Manis Baru Kecamatan Air Kumbang Kabupaten Banyuasin. Dalam penelitian ini, peneliti menerapkan strategi pembelajaran modeling dalam menulis teks berita untuk kelompok eksperimen, sedangkan kelompok kontrol, peneliti tidak menggunakan strategi pembelajaran modeling.

Kenyataan di lapangan saat menggunakan strategi pembelajaran modeling dalam menulis teks berita diperoleh bahwa siswa lebih aktif dalam berkelompok sehingga melibatkan siswa secara langsung dan berdiskusi saat bekerja kelompok. Untuk kelas kontrol peneliti hanya menjelaskan materi dan siswa kebanyakan diam dan ada yang mengantuk ataupun berbicara dengan teman sebelahnya.

Penelitian ini dilakukan pada dua kelas sampel. Dalam menentukan sampel, peneliti menggunakan teknik random sampling sehingga diperoleh kelas VIII B (kelas eksperimen) dan kelas VIII C (kelas kontrol). Kelas eksperimen diajarkan menggunakan model artikulasi, sedangkan kelas kontrol diajarkan dengan metode ceramah. Penelitian ini menggunakan metode eksperimen, sedangkan jenis 
Pembelajaran Menulis Teks ....(Liza Murniviyanti)

eksperimen yang digunakan oleh peneliti adalah true experimental design dengan bentuk posttest-only control design. Pemilihan penggunaan metode tersebut bertujuan untuk membedakan kelas eksperimen dan kelas kontrol. Peneliti mengharapkan adanya perbedaan antara hasil belajar siswa kelas eksperimen dengan siswa kelas kontrol. Rata-rata nilai tes awal dan tes akhir belajar siswa kelas VII.a (kelas eksperimen) dalam membuat kalimat dari isi berita dengan menggunakan model pembelajaran modelling adalah $\mathrm{Rn}$ awal 62,03 dan $\mathrm{Rn}$ akhir 82,64 .

Dari hasil penelitian yang dilakukan terhadap sampel yang berjumlah 72 orang siswa yang terdiri atas 36 orang siswa kelas eksperimen dan 36 orang siswa dari kelas kontrol. Berdasarkan hasil perhitungan yang didapat untuk kelas eksperimen, uji normalitas data diperoleh nilai $\mathrm{Km}=0,49$ sedangkan untuk kelas kontrol diperoleh $\mathrm{Km}=0$,91 dan harga tersebut terletak antara $(-1)$ dan $(+1)$ sehingga dapat dikatakan bahwa data kelas eksperimen dan kelas kontrol berdistribusi normal. Untuk pengujian homogenitas data diperoleh $x^{2}{ }_{\text {hitung }}=12,09$ dan $x^{2}{ }_{\text {tabel }}=-1$ dan diketahui syarat dari homogen data adalah $x^{2}{ }_{\text {hitung }} \leq x^{2}{ }_{\text {tabel }}$ dimana pada perhitungan diperoleh $12,09 \leq 13,78$. Dari hasil tersebut dapat dikatakan bahwa sampel berasal dari populasi yang sama.

Dari hasil analisis data dengan menggunakan Uji-t diperoleh hasil $t_{\text {hitung }}=$ 0,93 dan $\mathrm{t}_{\text {tabel }}$ untuk taraf nyata $(\alpha)=0,05$ peluang $(1-\alpha)$ dan $\mathrm{dk} 70$ didapat $\mathrm{t}_{(0,95)(70)}$ $=-1,67$ maka $t_{\text {hitung }}>t_{\text {tabel }}$ yaitu $0,93>1,67$ hal ini berarti $H_{a}$ diterima. Dengan demikian hipotesis yang dikemukakan peneliti, ada pengaruh model pembelajaan yaitu modeling terhadap hasil belajar siswa kelas VII pada mata pelajaran Bahasa Indonesia di SMP Negri 41 Palembang 2016-2017 diterima kebenarannya. 


\section{SIMPULAN}

Berdasarkan hasil tes dan pembahasan, dapat disimpulkan bahwa ada pengaruh yang signifikan bahwa, MTs Nurul Hikmah Siswa kelas eksprimen berjumlah 31 orang siswa sedangkan kelas kontrol berjumlah 31 orang siswa, dari hasil tes yang dikerjakan siswa maka didapat jumlah nilai tes akhir siswa kelas eksprimen adalah 29,16, nilai rata-rata adalah 81 dan jumlah nilai kelas kontrol 1936, nila rata-ratanya adalah 53,77. Uji normalitas data kelas ekprimen $\mathrm{km}$ terletak antara -1 dan $+1 .-1<\mathrm{km}<+1$ yaitu $-0,27$ dan kelas kontrol km terletak antara -1 dan $+1 .-1<\mathrm{km}<+1$ yaitu $-0,18$.

Homogenitas data adalah $f_{\text {hitung }}<f_{\text {tabel }}$ yang menunjukan bahwa varians kedua kelompok yang dibandingkan adalah homogen $f_{\text {hitung }}=1,47<f_{\text {tabel }}=1,88$ bersifat normal dan homogenitas maka di uji dengan uji-t yaitu uji hipotesis yang mana diketahui bahwa $t_{\text {hitung }}>t_{\text {tabel }}$ yaitu $12,80>1,66$. Dengan demikian dapat dikatakan bahwa Ho ditolak dan $\mathrm{Ha}$ diterima atau ada pengaruh strategi pembelajaran modeling dalam menulis teks berita siswa kelas VIII MTs Nurul Hikmah.

\section{DAFTAR PUSTAKA}

Achmad. (2012). Linguistik Umum. Jakarta: Erlangga.

Chaer, Abdul dan Leonie Agustina. (2010). Sosiolinguistik Perkenalan Awal. Jakarta: Rineka Cipta.

Chaer, Abdul. (2012). Linguistik Umum. Jakarta: Rineka Cipta.

Darmawati, Uti. (2009). Ragam Bahasa Indonesia. Klaten: Intan Pariwara.

Husnul, Ade. (2010). Berwawancara Dengan Narasumber. Bogor: Quadra.

Kurnia. (2014). Bahan Ajar Linguistik Umum. Palembang.

Mulae, Sunaidin Ode. (2015). Pengantar Morfologi. Yogyakarta: Morfalingua.

Sumadia, As Haris. (2011). Jurnalistik Indonesia Menulis Berita dan Feature, Bandung, Simbiosa Rekatama Media.

Tarigan, Henry Guntur. (2009). Pengajaran Morfologi, Bandung, Angkasa. 